\title{
Suburban Identity in the Poetry of John Updike
}

\author{
Jiří Flajšar \\ Palacký University, Olomouc, Czech Republic
}

This paper provides a close reading of a representative selection of suburban poems by the American writer fohn Updike (1932-200g). It also draws upon the existing scholarship by suburban studies historians (including Kenneth Jackson, Dolores Hayden, Fohn Archer, and Fames Howard Kunstler), who have argued for the cultural importance of American suburbia in fostering identity, and develops the argument by literary critics including Fo Gill, Peter Monacell, and Robert von Hallberg, who have championed the existence of a viable suburban tradition in postwar American poetry. By scrutinizing poems from Updike's early poetry, represented by "Shillington", up to his closing lyric opus, "Endpoint", the paper argues that Updike's unrecognized importance is that of a major postwar poet whose lyric work chronicles, in memorable, diverse, and important ways, the construction of individual identity within suburbia, in a dominant setting for most Americans from the 1950 up to the present.

\section{Keywords}

John Updike; American poetry; suburbia; criticism; history; $20^{\text {th }}$ century

While the fiction of John Updike (1932-2009) has received significant critical attention, his poetry has been mostly ignored. My aim is to analyse the role of American suburbia in Updike's poetry and its function as a setting that helps construct the identity of the autobiographical speaker in his poems. Although this theme is prominent within Updike's substantial poetic oeuvre, it has not been yet explored in an adequate manner. The author of nine poetry collections, Updike was preoccupied, throughout his career which spanned six decades, with using American suburbs and small towns as the setting for many poems. Within a twentieth-century tradition of critical denunciation of suburbia as a culturally dead and conformist wasteland, Updike was, from early on, able to craft a body of suburban poems through which his identity is revealed. In an early defence of postwar suburban poetry, Robert 
von Hallberg claims that numerous major poets of Updike's generation increasingly wrote about suburbia as insiders, manifesting "greater sympathy with suburban subjects" (American Poetry 239) and positing the suburban experience as central to identity formation after WWII. As Jo Gill has shown, postwar American poetry such as Updike's has played an important role "in the construction and dissemination of an image (or images) of suburban landscape, daily experience, and subjectivity" (Poetics 16). Brad Leithauser explains that Updike's poetry "gives us a remarkably full autobiographical portrait", exploring without the usual detachment of persona from the subject matter of Updike's life as "an album of himself more accurate and intimate and multifaceted than any similar-sized collection of [Updike's] prose" ("Updike's Naked Poetry"11-12).

The survey of suburbia as a setting conducive to the construction of the poet's identity begins with an early poem, "Shillington", in which the adult poet revisits one of the suburbs of Reading, Pennsylvania, with the gesture of homecoming after a long absence:

The vacant lots are occupied, the woods

Diminish, Slate Hill sinks beneath its crown

Of solvent homes, and marketable goods

On all sides crowd the good remembered town. (1-4)

The change of Shillington from a charming small town of the prewar era to a fast-growing postwar metropolitan community enclosed by uniform suburban enclaves, is typically American. The poem provides testimony to the negative effects of suburban sprawl, which Dolores Hayden calls "a process of large-scale real estate developments resulting in low-density, scattered, discontinuous car-dependent construction, usually on the periphery of declining older suburbs and shrinking city centers" (Field Guide 8). The town of Updike's youth, where he lived with his family until he turned thirteen, is destroyed by the influx of consumerist newcomers. The poet reacts to this development by blaming his faulty memory: "Returning, we find our snapshots inexact" (5). He acknowledges life as defined by the inexorable sequence of major and minor losses, which is "a condition of being alive" (6), likened to the state of having grown out of the old clothes which, "setting out, we packed / With love" and yet these "no longer fit when we arrive" (7-8). The poet has changed as much as the town he used to know and both the town and his clothes no longer fit his adult identity. There are, however, locals who still 
try to maintain the old-time atmosphere of Shillington as "the town that we have lost / Is being found by hands that will arrange / Horse-chestnut heaps and fingerpaint on frost" (10-12). By the end of the poem, Updike accepts the disillusion which a return to one's hometown invariably brings: "We have one home, the first, and leave that one. / The having and leaving go on together" (19-20). For Updike, the loss of past spaces and memories goes hand in hand with the need to continue his emotional possession of the town. As Adam Begley documents, Updike's "subsequent departures from other places he lived (Plowville, New York City, Ipswich) always involved a reenactment of sorts, echoes, however faint, of that early exodus" from the small-town idyll of his youth. (Updike 32). According to Gill, "Shillington" commemorates "not just the place itself [...] but the collective and now poetic process of imagining, remembering, and tracing the textures of lost and present times, places and communities" (Poetics 123). If the poem is a little ruthless in the poet's appropriation of his hometown, such a possessive attitude toward a place is far from exceptional. As Richard Hugo has argued, to write a good poem about a town, one should "assume emotional ownership of a town or a word", which is "narcissistic, vain, egotistical, unrealistic, selfish, and hateful" while being an essential approach for the creation of rhetorically credible poems about an urban setting (Triggering Town 14).

Another early Updike poem, "Suburban Madrigal", is a probe into the postwar middle-class male identity in suburbia. It focuses on the suburban house as the locus of identity-shaping battles within the poet's self and beyond. The house in American suburbia, as John Archer documents, has come "to be understood as an essential apparatus for fashioning the self-made man, a direct route to achieving the American dream, and a primary instrument for establishing class, status, personality, character, and even aspects of race and faith" (Everyday Suburbia, 25-6). Updike's poem, with its title, relates a classical domestic song from Renaissance Europe with the poet's sense of belonging to the cultured elite of postwar American suburbia. Edward Brunner explains that such poetry by Updike and other poets such as the somewhat older Richard Wilbur, was meant "to accommodate a new postwar audience $[\ldots]$ that expected poetry to entertain them, instruct them, and convince them of their importance" (x). What Brunner further says of Wilbur applies again to the poetry of Updike as well, as the lyric work of both poets "valued intelligence, presented itself in a compressed fashion that was both efficient and elegant $[\ldots]$ and honored the value of observing everyday events" (x-xi). In "Suburban Madrigal", Updike assumes the viewpoint of a home-bound, 
self-complacent, cultured suburbanite who cherishes his material and social achievement in suburbia while indulging in an imagined act of trespassing upon the property of his neighbor:

Sitting here in my house, looking through my windows, diagonally at my neighbor's house,

I see his sun-porch windows; they are filled with blue-green, the blue-green of my car, which I parked in front of my house, more or less, up the street, where I can't directly see it. (1-9)

The poem utilizes the suburban gaze which is directed outward, from the poet's house towards the other, his neighbor's. The poet enjoys his having "broken" into the neighbor's property via the reflection of his car in the neighbor's window, and, of having accomplished symbolic violation of the latter's identity. The line-crossing fantasy goes deeper than seems at first sight, for, as Constance Perin explains, Americans are obsessed with maintaining their privacy and they "seldom let their property lines lose their edges" (Belonging 29). Moreover, "Suburban Madrigal" celebrates the dramatic effect of the static reflection of the car as a welcome diversion from the domestic ennui of the poet's suburban routine: "How promiscuous is / the world of appearances! / How frail are property laws!" (10-12). The poet's identity is constructed through the implementation of a private trespassing joke whereas the absent neighbor is only implied as the injured party to the poet's mental construction. As Gill points out, the neighbor is described solely through his possessions, which is symptomatic of "the alienating and acquisitive aspects of postwar suburbia" (Poetics 135). The poem's second and final stanza further elaborates the glee of the speaker's private satisfaction brought about by the fantasized encroachment upon the possessions of the unwitting neighbor for whom his suburban window suggests a sense of privacy and security, being "filled with his / things: his lamps, his plants, his radio" (13-14). Robert Beuka emphasizes the significance of windows in the construction of identity in American suburban literature, with the picture window of the American house typically serving as a "mirror...through which middle-class American culture casts its uneasy reflective gaze on itself" (SuburbiaNation 4). However, if the 
poem's reliance upon the visual aspects of suburban ownership suggests "the refusal of communication, or, more properly, a deceptive promise of openness both for the insider looking out and the outsider looking in", the real function of suburban windows is their two-way ability to "evoke concerns about the relationship between self and other, family and polis, here and there, subject and viewer or voyeur" (Gill, Poetics 134). In "Suburban Madrigal", the perception of the poet's own, and the neighbor's, property is crucial to the realization of the poet's identity as a self-complacent property owner who, unusually for a suburban father, has the luxury of spending his days at home, observing, thinking, and writing. The poem ends with Updike's speculation as to the intensity of annoyance that the neighbor would feel if he realized

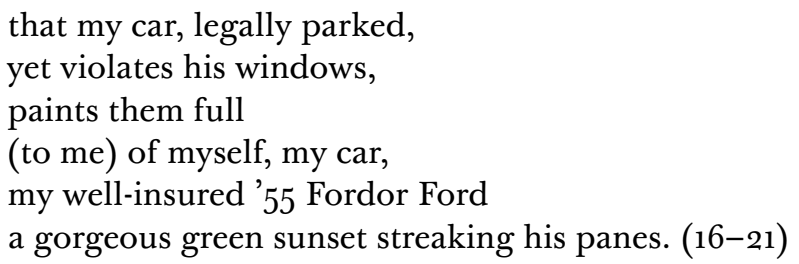

The poem is symptomatic of the trend in American suburban poetry to dramatize the suburban lack of drama for comic or absurdist effect. As Leithauser has shown, Updike's speaker here winds up being “the meticulous onlooker who could hardly be described as an interloper or a trespasser, since the autonomous body under consideration is oblivious of any surveillance" (11). The humorous absurdity of the poem's conceit is in the exaggerated value which the speaker places on being able to enter the untouchable space of his neighbor's. According to Gill, both the poet and his neighbor are complicit in this imagined suburban drama, for both parties are "vulnerable to scrutiny and violation by the other" (Poetics, 135). However, Updike's speaker takes great care to remain a law-abiding citizen whose belief in the sanctity of house and car ownership and in the borders of his estate is not to be challenged by anyone including himself. The poem also explores the viewpoint of the suburban male who enjoys the benefits of being sheltered in his suburban house, in what Kenneth T. Jackson has called "a private haven in a heartless world" (Crabgrass Frontier 243). This angle becomes typical for the postwar American writer, a suburbanite who assumes the role of laid-back observer rather than direct participant in the activities of his street, reflecting the shift in the way Americans became, as Jackson documents, loners "centered inside 
the house, rather than on the neighborhood or the community" (Crabgrass 279). According to William $H$. Chafe, the average male suburbanite in postwar America could not afford to stay at home during the working hours of the week since he would have to commute to work, leaving

the home almost before daybreak, returning just in time for a romp with the kids, perhaps a quick swing, and then a kiss goodnight. Mothers, meanwhile, held down the fort at home, cleaned the house, transported the children to their daily activities, participated in various P.T.A. and church groups, and still found time, in the midst of all, for kaffeeklatsching with women friends and discussing childrearing" (Unfinished fourney 123-4).

The protagonist of "Suburban Madrigal", as a writer, does not "work" in the traditional sense of having a daytime male job that would take him away from his home. Rather, he is able to stay in, observing what goes on in the suburban community, assuming the role of the observant neighbor who monitors what is happening on the block from behind the curtains. ${ }^{1}$

The suburban setting is crucial for the construction of the poet's identity even in many other Updike poems. In "Wash", the image of a neighbor's clothes that have been scattered about by a recent storm become agents of a visionary transformation in faithless and uncultured suburbia, "thronging the sunshine / With hosannas of cotton and halleluiahs of wood" (Collected 25). ${ }^{2}$ The clothes are attributed supernatural qualities as, assisted by the wind, they "rushed into all the back yards / And lifted up their arms in praise" (5-6). In the absence of spiritual nourishment in postwar suburbia, trying to find fulfilling experience in a setting whose uncultured uniformity was dismissed by social critics such as Lewis Mumford as "a low-grade uniform environment from which escape is impossible" (City in History, 486), it is the task of the poet to seek redemption in imagined transformation of the mundane detail such as laundry strewn about into epiphanic vision that is out of proportion to the situation which starts it. Updike's poetry is full of suburban trivia which suggests that Mumford's criticism may have been correct. In "Burning Trash", the regular suburban activity of burning the household waste becomes a way to fight the spectre of "nothing standing like a sheet / Of speckless glass behind his human future" (Collected 9). In "The Short Days", Updike admits to his penchant for "the way, in winter, cars / Ignite beneath the lingering stars / And, with a cough or two, unpark, / And roar to work still in the dark" (Collected 32). As in "Suburban Madrigal", the poet here enjoys the privilege 
of being able to observe his neighbors including the housewives who "wash doubts / Down sinks and raise the glowing shades" (11-12). The passage of time from morning to night reflects the cyclical nature of the neighbors' routine, with life framed by the morning departure of the men to work and their evening reappearance to be reunited with their families: "The cars are gone, they will return / When headlights in a new night burn" (13-14). The cycle of presence and absence of the poet's neighbors is likened to the renewal of energy in the natural world, with its perennial cycle of day and night, growth and dormancy.

Another crucial suburban poem by Updike is "My Children at the Dump", in which the author abandons the self-complacent mask of suburban achiever and dramatizes the ambivalent feelings of a father who fears impending divorce while taking his children to a dump for toy-hunting. With the choice of setting, Updike echoes a Wallace Stevens poem, "The Man on the Dump", yet the setting is where the similarities between both poems end. ${ }^{3}$ While the Stevens poem launches into the usual linguistic fireworks to meditate, in Stevens's trademark flowery and impenetrable language, on the vicissitudes of being, the Updike poem focuses on the palpable discrepancy between the innocence of the speaker's children who "are enchanted by / a wonderland of discard where / each complicated star cries out / to be a momentary joy" (Collected 35). The speaker is reserved and melancholic since he is able to interpret the dump waste as reflecting the short life of suburban consumer products as well as foreshadowing the break-up of his marriage:

Sheer hills of television tubes, pale lakes

of excelsior, landslides

of perfectly carved carpentry-scraps,

sparkplugs like nuggets, cans iridescent

as peacock plumes, an entire lawnmower

all pluck at my instinct to conserve. (lines 7-13)

The speaker's "instinct" is not to preserve the discarded objects and fragments he sees. Rather, he projects the wish to keep his family together onto the landscape of the dump which solicits both fascination and disgust. Gill concurs that the discarded objects of the dump function as "a metaphor for the irretrievable breakdown of the speaker's relationship and family circle" (41). However, the speaker refuses to comply with his children's wish to salvage some of the broken toys from their fate: "I cannot. These things / were 
considered, and dismissed / for a reason" (14-16). While the children keep bringing various fragments which they would like to keep, their father refuses to allow this, arguing that his motivation is to purify his soul by adding his "fragments to this universe of loss, / purging my house, ridding a life / no longer shared of remnants" (28-30). The poem juxtaposes pain, sadness, and wonder at the way in which even the best products of consumerist America finally disintegrate, which suggests similarity to the short-lived course of the speaker's marriage. The poet finally prevents his daughter from taking back home "a naked armless doll, still hopeful in its dirty weathered eyes" (31-2) by taking a firm stand: "Love it now, but we can't take it home" (34). "My Children at the Dump" is an unusual poem which juxtaposes the reaction of children and adults to family crises, exposing the different sensibility of each group against the backdrop of discarded objects in the dump.

Suburban identity has also been defined by the visual media. In "Home Movies", the iconic postwar pastime of recording one's suburban family with a black-and-white silent film camera is explored by the parent whose adult children visit for the showing: "Pale infants, squinting, seem to hark / To their older selves laughing in the dark" (Collected 52). The rueful tone of the adult children and parents who watch footage featuring their younger selves suggests the futile but honest impulse of the American suburbanites to freeze moments of youthful innocence and happiness forever: "We cannot climb back, nor can our friends / To that calm light. The brief film ends" (11-12).

As has been shown, Updike's suburban poetry is frequently marked by a tendency to define his identity within a framework of house, garden, and relationships to family members and neighbors. In "The House Growing", Updike meditates on the dilapidation of his ancestral suburban home, which "grows, adding rooms of silence" to the memories of his grandparents and father, whose recent deaths the poem commemorates. Now that they are gone, the house "grows vast. / Its windows take bites of the sky / to feed its flight toward emptiness" (Collected 116). The fear of death is a constant presence in the Updike suburb, a setting which is occupied as much by the ghosts of his ancestors as by the notable absence of surviving family members.

Although Updike always felt proud of his Harvard education, he would also voice his ambivalence about the real value of such privileged schooling upon his own development as writer, father, and lover. In "Apologies to Harvard", a 1973 annual poem for the Phi Beta Kappa Society at his alma mater, he outlines the future for the audience of young graduates by comparing it with his own career as a famous alumnus (Collected 120-5). He reminisces 
about the way he was, nineteen years before, "hatched and certified your [i.e., Harvard's] son" (line 16), an achievement that enabled him to assume the fullfledged position of someone who became "steeped in speed and song, / In Doctor Spock, TV, and denim chic / Has come and gone since, Harvard, we swapped vows / And kept them" (17-20). Using culinary terminology, Updike describes his Harvard student experience as being initiated, "raw as I was", chewed, and spat out, "by God, a gentleman" (36-8). A member of the class of 1954, Updike feels qualified to comment on the 1950s, the decade in which he graduated, became established as a writer, and started a family in the suburbs: "The Fifties - Cold War years par excellence - / Loom in memory's mists as an iceberg, slow / In motion and sullenly radiant" (54-6). That decade has, by the 1970s, become the source of nostalgia for "the only life / Worth living was the private life" (138-9), an attitude which culminated in the young graduates' postwar decision to stake out conformist identities:

We went forth, married young, and bred like mink.

We seized what jobs the System offered, raked

Our front yards, stayed together for the kids,

And chalked up meekly as a rail-stock-holder

Each year's depreciation of our teeth,

Our skin-tone, hair, and confidence. (144-9)

As James Howard Kunstler argues, the "creation of a suburban culture" in the postwar years was a telling sign of the value of suburban conformity as it "augured an era of boundless prosperity, security, comfort, and ease" (Geography 105). Updike's sardonic appraisal of the 1950s reflects the attitude noted by Chafe about the "quest for meaning in suburbia", which proved, like other social developments of the time, "related to the existentialist dilemma of finding a way to create meaning in the face of [social] forces over which one had no control" (Unfinished fourney 136). "Apologies to Harvard" ends with a good-luck message to the young graduates whose careers might, someday, rival Updike's own: "The possible / Is but a suburb, Harvard, of your city. / Seniors, come forth; we crave your wrath and pity" (151-3). The closing couplet relates Harvard to the suburbanization of postwar America as well as to the fact that the university itself lies in an early suburb of the city of Boston.

If Updike's suburban poems maintain a degree of autobiography that might be equally found in his fiction, the poems keep more of an ironic distance from personal and painful subject matter. "Sleepless in Scarsdale" is another 
celebration of suburban achievement, however, the values of the poet's identity are inverted from what Updike presents in "Suburban Madrigal". The poet presents an insomniac meditation on the maddening normality of the suburban home and family of a friend he is visiting. The perfection of the household he visits is contrasted with the impurity of the poet's nocturnal thoughts:

Downstairs, the furniture matches.

The husband and wife are in love.

One son in Yale, another in law,

a third bowls them over in high school. (Collected 129-30)

To disturb the impeccable image of the host family, the speaker longs "for squalor's relaxation, / fantasizing a dirty scene" (lines 10-11). The rare sound of a few steps prompts him to imagine further disruption of the domestic suburban idyll: "A burglar has found us. A son / is drunk. The wife desires me" (19-20). However, these are all fabrications, since "nothing happens, not even / oblivion" and the poet mock-seriously complains that in American suburbia, life "can be too clean" (21-2). Considering himself the only living soul in a fashionable suburb on a particular night, the poet keeps on waiting to fall asleep or to meet the devil, or, "one with whom I can make a deal" (28). This imagined rebellion against the suburban conformity of his friends might also be read as what Beuka calls "an attempted psychological retreat from the alienating, commodified landscape of suburbia" (SuburbiaNation 238). In "Sleepless in Scarsdale", Updike dons the mask of a suburban rebel without a cause, a visitor to a family so ideal and perfect that its image has to be seasoned with imagined acts of transgression.

Overall, Updike seems to have written more intimate suburban poems about houses than about people. In "The Melancholy of Storm Windows", the gradual degradation of an iconic part of the house is likened to the way people age and crumble in suburbia:

They resemble us, storm windows, in being gaunt, in losing putty, in height, transparency, fragility weak slabs, poor shields, dull clouds. (Collected 146)

"An Oddly Lovely Day Alone" revives the pattern of suburban meditation of the lonely, house-bound writer whose wife and children are away and who 
spends the day alone reading, writing, and doing minor chores. The crucial change happens when the poet realizes that his lonely days, however eventful and creative, are meaningless until touched by epiphanic transformation of the everyday: "Each hour seemed a rubber band / the preoccupied fingers of God / were stretching at His desk" (Collected 157). That the religious undertone of Updike's poetry has been overlooked is confirmed by John McTavish who claims that while Updike's fiction merely "dramatizes the ambiguous lives of his thoroughly human characters", in his poetry he "occasionally steps forward" and firmly "declares what he believes" (434). Ultimately in Updike's poem, it gets dark outside and it starts to snow, "a fantastic effect" which forces Updike to crack a joke to end his unusual mediation with a sobering thought: "If people don't entertain you, / Nature will" (Collected 158).

A crucial poem about the ambition of a typical male breadwinner to leave a lasting legacy within the urbanized suburban environment is "Planting Trees" (Collected 169-70). In an echo of Talmudic wisdom, Updike explores the significance of planting a tree and living long enough to see the tree grow to maturity, thus honouring the "last connection with the mythic" (line 1). While the first and second stanzas celebrate the longevity of the poet's ancestors, his mother and "the old farmer" who "treads through the orchard he has outlasted" (9-10), the final stanza focuses on his own tree-planting plan: "At the back of our acre here, my wife and I, / freshly moved in, freshly together, / transplanted two hemlocks that guarded our door" (17-19). The planting assumes historic significance as Updike imagines the life-span of the hemlock tree as transcending his own. The tree becomes a long-lived projection of himself, growing from a pair of "green gnomes a meter high" (20) to being replanted in the back garden, where the one surviving tree of the pair "some day will dominate / this view no longer mine" (22-3). Finally, Updike imagines a return to his suburban house as a stranger, "an old man, a trespasser, / and remember and marvel to see" the tree grown to loftiness, "so amplified, like a story through layers of air / told over and over, spreading" (26-30). The achievement of "Planting Trees" is the juxtaposition of the human and arboreal lifespan and the portrayal of the ways in which the suburban history of trees and people intersects. Peter Monacell agrees that suburban spaces, both indoor and outdoor, provide "a basis on which to build literary individuality, and an arena in which the [poet's] imagination can continue its transformative work" ("In the American Grid" 137). Updike's "Planting Trees" is exactly a poem where the human, natural, and artificial traces in American suburbia memorably intersect. In "Planting a Mailbox", 
the occasion of a minor DIY construction project becomes a way to celebrate the fact of owning a suburban homestead, "a branch post office" whose position by the road marks the accomplishment of its maker (Collected 292). In "Long Shadow", the late summer season allows the "freedom to move in few clothes", and yet the ripening leaves in the poet's neighborhood mark the coming of autumn in suburbia, with "news broadcast red from the woods to the west" and "the goldleaf woods of shedding branch and days / drawing in like a purse being cinched" (Collected 183). Understandably, the autumnal mood portrayed in the poem makes Updike muse on mortality as he observes the immense length of his shadow cast upon the ground: "Stretched / like a rainbow across day's end, my shadow / makes a path from my feet. I am my path" (12-14). The changeable nature of the shadow reflects the changing, fragile, and impermanent nature of the poet's own precarious life and identity crafted within suburbia which is, like his shadow, forever subject to change and danger from the outside.

Despite the abundance of personal poems rooted in American suburbia, there is surprisingly little in Updike's poetry about the intimate details of his suburban marriages and affairs - women are typically marginalized objects whose sole task is to please the poet's libido, as in "Living with a Wife" and "Sleeping with You" (Collected 103-5, 188). In rare moments of self-awareness, Updike admits to failing to understand the female sensibility in a relationship, finding his wife "as unaccountable / as the underwear set to soak / in the bowl where I brush my teeth" (Collected 105). Naturally, critics such as David Foster Wallace have complained about the limits of Updike's chauvinist phallocentrism, yet even Wallace admits that Updike admirably explored the fictional alter egos of himself, a white middle-class male New England suburbanite who is "always incorrigibly narcissistic, philandering, self-contemptuous, self-pitying [...] and deeply alone, alone the way only a solipsist can be alone" ("John Updike, Champion"). In Updike's poetry, however, one finds occasional glimpses of intimacy between two people, for example, in "Hot Water", Updike fashions the dream of an empty suburban mansion which is to be shared by the poet and his love: "Out comes, first, rust, / with a belch that shakes pipes behind plaster, / then cold, then tepid water, and, lastly, hot. / Hot water! The house is alive" (Collected 214). The turning on the faucet becomes an act of warming the house and the relationship as the couple "are enough in our flesh / to warm the hands of another by; we are/ hot water, here among the icy stars" (lines 12-14). In "Enemies of a House", Updike provides a catalogue of all possible problems, pests, and sources of 
decay that threaten a house's health: "voracious ivy, frost heaves; splintering; / carpenter ants; adultery; drink; death" (Collected 222). In "Pillow", the absence of a loved "other" is jokingly downplayed in the poet's comical address to his own pillow, which, like a woman, accepts "the strange night" with the poet and is "depressed / when the morning discloses your wrinkles" (Collected 223). In "The Millipede", getting rid of a kitchen pest becomes an occasion for rare marital communication between the estranged husband and wife, "the real housekeeper" (Collected 230).

Updike's late poetry is increasingly steeped in nostalgia about the past and haunted by the loss of memories, people, and relationships. For Updike, the way to deal with the epistemology of loss is to immortalize the notable moments of his life in poems. In "To a Dead Flame", the history of an affair long past is ruefully recounted by the poet who addresses his deceased lover while being aware of his own diminishing prowess:

You dropped out, but we all drop out, it seems.

You never met my jealous present wife, she hates this poem. The living have it hard, not living only in the mind but in the receding flesh. (Collected 248)

Updike treats the grim subject of aging with humorous undercutting, following a poetic strategy which Ronald Wallace calls brandishing "a weapon against chaos and despair in a world that seems increasingly indifferent and absurd" (God Be with the Clown 5). "Brasil" is a poem about late-life globetrotting which makes the poet realize where the real knowledge about life should be sought: "To go to the edge is to discover / the edge to be the center" (Collected 252). The poem ends with a witticism that shows Updike's awareness of being an egotist who obsessively explores the suburban self in an effort to come to grips with the world at large: "To arrive at self's end is to embark again / upon love's narcissistic enterprise" (lines 13-14). Like the early colonists in America, the protagonists of Updike's middle-class world choose suburbia as their environment as the destination of their escape from themselves, a culmination of what D. H. Lawrence famously defined as the quintessential American impulse of the pioneer "to get away - that most simple of motives. To get away. Away from what? In the long run, away from themselves. Away from everything" (298). The only difference is, for Updike, that the suburban frontier is not a dream environment located beyond reach but, rather, the 
suburban experience to be found at home as well as just outside one's picture window.

The protagonist of Updike's suburban poems, himself, or his alter-ego as the former lion of suburban parties, is increasingly featured, in the late poems, as an aging man in a crumbling marriage who is ever on the brink of "running away". ${ }^{4}$ Updike's poems, moreover, manage to blend the conformist approach of a model successful suburbanite whose house has become, as John Archer documents, "recognized as one of the premier instruments for satisfying the expectations of selfhood in America" (Architecture and Suburbia 292). In "Academy", Updike speaks like a melancholic, aging social lion whose "shuffle up the stairs" betrays his advancing age and whose intellect has "sunk to polite senility" while his perennial ambition to impress others with his accomplishments as an American author, critic, artist, lover, husband, father - these roles are likened to battles which "were fought elsewhere" while "we wake to bright bald honors" (Collected 254).

While Updike consciously divided his poetry into light verse and serious poems, many compositions, including the suburbiana that are surveyed in this article, dissolve the hazy line between both genres. ${ }^{5}$ In "Superman", a seemingly light-verse take on suburban consumerism assumes the ambivalence of a serious poem:

I drive my car to supermarket,

The way I take is superhigh,

A superlot is where I park it,

And Super Suds are what I buy. (Collected 270-1)

The cult of conspicuous suburban consumption is ridiculed by the bombast of the speaker who boasts of being the top in any field, daring anyone to rival him, the "Super-super-superwho?" (line 16). Updike's outrageous joke conveys serious social commentary about the meaning of self-presentation in the suburban culture which privileges success at all costs. As Edward Field has argued, the evaluative division between light and serious verse "has almost ceased to exist", even if humour remains "a major element in many poets" bag of tricks" (Geography of Poets xlii). Similarly, in "Thoughts While Driving Home", Updike seemingly waxes comical, and yet the poem's sprightly meter and rhyme belie the serious message underneath: 
And did I, while being a smarty,

Yet some wry reserve slyly keep,

So they murmured, when I'd left the party,

"He's deep. He's deep. He's deep"? (Collected 305)

Although Updike's poetry of the 199os and 200os all but abandons the suburban setting, there is one meditation, "In the Cemetery High Above Shillington", which rightly belongs to the tradition of American suburban literature ("In the Cemetery" 25-9). The poem begins with a scene in which the poet as a fifth-grader, along with other boys of his age, "thread tricolor strips / of crépe paper through our bikes' staggered spokes" to take part in a Memorial Day Parade (lines 1-2). The boys play around the cemetery without any understanding of its grim meaning: "we dimly listened, kidded and horsed around / there on the grit and grass, and pedalled home" (16-7). The rest of the poem is cast fifty years after the first poem, "Shillington", described above, as the poet nears his end:

$[\ldots]$ In a rented car, on idle impulse, briefly home, if "home" is understood as where one was a child, I glide into this long-forgotten space (19-22)

In the stanzas that follow, Updike gives a moving portrait of Shillington's dead citizens including family members, drawing on his memory, as well as prompted by the sight of their gravestones: "I find here what the live town lacks, some friends - / some people I once knew" (30-1). Yet Updike rejects the typical cemetery blues with his mock-poetic versifying: "Never shall I so lie, in trimmed green silence, / among the earners of this resting-place" $\left(165^{-6}\right)$, sharing "the Shillingtonian ethos, the mild / belief that Earth's safe center has been found" (168-9). Instead, Updike recognizes here the value of his suburban roots which he has tried to move beyond, saw the futility of, and is meekly coming back to:

I am your son; your mile-square grid of brick the little terraces, the long back yards contains my dream of order, here transposed to an eternal scale. $(172-5)$ 
Having imagined the gone lives of his Shillington contemporaries, Updike justifies the personal tone of the poem as his "formal protest against the forgetting / that lets the living live" (181-2). The poem departs from the usual Updike treatment of the American suburb as a landscape that is best served by whimsical introspection in order to mask a darker, realistic view of life. In "Endpoint", the final long poem of Updike's career, he deals with his own imminent death from cancer while meditating on the Shillington of his youth and the trauma of his departure from that idealized setting as

\author{
I had to move \\ to beautiful New England - its triple \\ deckers, whited churches, unplowed streets - \\ to learn how drear and deadly life can be. (Endpoint 27)
}

The poem, written in separate takes over the span of the 2000 and reaching up to a few days before Updike's death in January 2009, aptly ends with a personalized revision of a phrase from Psalm 23:6, with the poet assuring himself that "goodness and mercy shall follow me all / the days of my life, my life, forever". ${ }^{6}$ While this very final bit of poetry sums up Updike's ambivalent attitude to organized religion ("Why go to Sunday school, though surlily, / and not believe a bit of what was taught?" (lines 1-2)), the final recourse to a psalm and its calming reassurance marks Updike as a poet of "fine religious sensibility" (McTavish 433).

William Deresiewicz calls Updike's Rabbit tetralogy of novels "a great symphony of American junk, accumulating in suburbs and arteries, of American lives, killed and wounded in families and wars" ("A Great Symphony"). With such a claim, he might have been talking about Updike's suburban poems as well. Arguably, Updike's best fiction and poetry rely on the exploration of the writer's ambivalence about his suburban milieu. On the one hand, Updike portrays the suburbia of his youth as a mixture of "Eden and exile", an experience to which he and the protagonists of his poems and fictions respond with an impulse to "escape and return, flight and fall, running and remembering" (Deresiewicz, "A Great Symphony"). Updike's exploration of his several suburban homes as versions of domestic ideal whose construction is mental rather than physical link his poetry to that of many other postwar American poets whose suburban poems, as Larry Levis documents, invariably "celebrate loss, they celebrate Eden - the myth of the place in the psyche" ("Eden and My Generation" 472). On the map of postwar American poetry, 
Updike's me-focused, personal poetry of suburbia belongs to the tradition of suburban insiders such as Phyllis McGinley, James McMichael, and Billy Collins, who celebrate the suburban identity of the poet as the realization of the American dream and downplay any sense of conformity and boredom. Instead, their poems pay homage to a vibrant culture of single-family detached houses which enable life in a pleasant, lush suburban environment of manicured lawns and growing trees, far from the madding crowd of the city and yet within reach of the city's cultural and economic advantages. Gill explains that the achievement of postwar suburban poetry has been to portray suburbia as "replete with meaning", reflected in a wide range of poems which are "often skilful, occasionally luminous, always intriguing" (Poetics 181). Mark Clapson thinks that the dream of suburban America has not been exhausted yet, rather, it keeps attracting new generations and, as a culture-founding myth, it "should be treated sympathetically and imaginatively" as American suburbs since the 1950s have functioned as "a residential environment free from decline and despair" (Suburban Century 197). Updike's poetry, from "Shillington" to "Endpoint", seems to have enriched the traditional debate about the ways in which identities are constructed in American suburbia. The fact that his poetry has been all but ignored by critics has little to do with the artistic merit of the work; the situation merely reflects the important, yet precarious position of poetry within American literary culture.

\section{Notes}

1. See, for example, Bachelor in Paradise, a 1961 film starring Bob Hope and Lana Turner. The protagonist, A. J. Adams (Hope), rents a house in a new suburb to work on a book while being carefully monitored by an elderly neighbor from behind her curtains. In Updike's suburban poems like "Suburban Madrigal", it is the male poet who does the monitoring.

2. A morning meditation prompted by the image of fresh laundry fluttering about in the wind was also notably explored by Richard Wilbur in "Love Calls Us to the Things of This World", in New and Collected Poems, by Richard Wilbur (San Diego: Harcourt, 1988), 233-4.

3. See Wallace Stevens, "The Man on the Dump", Collected Poetry and Prose, eds. Frank Kermode and Joan Richardson (New York: Library of America, 1997), 201-3.

4. See Updike's breakthrough novel from 196o, Rabbit, Run, in which the protagonist, Harry "Rabbit" Angstrom, keeps running away, physically as well as emotionally, from his roles as responsible husband, father, and son-in-law. See John Updike, Rabbit, Run (New York: Knopf, 1960).

5. Updike makes the following distinction between his light verse and poems: "a [real] poem derives from the real (the given, the substantial) world and light verse from the 
JIŘÍ FLAJŠAR

man-made world of information - books, newspapers, words, signs. If a set of lines brought back to me something I actually saw or felt, it was not light verse". See John Updike, Collected Poems, 1953-1993 (New York: Knopf, 1993), xxiii.

6. Cf the passage in Psalm 23:6, New International Version, which reads: "Surely your goodness and love will follow me / all the days of my life, / and I will dwell in the house of the LORD / FOREVER".

\section{Works Cited}

Archer, John. Architecture and Suburbia: From English Villa to American Dream House, 169o-2000. Minneapolis, MN: University of Minnesota Press, 2005. Print.

Archer, John. "Everyday Suburbia: Lives and Practices." Public: Art/Culture/ Ideas, 43. 2011: 22-30. Print.

Begley, Adam. Updike. New York: HarperCollins, 2014. Print.

Beuka, Robert. Suburbia Nation: Reading Suburban Landscape in Twentieth-Century American Fiction and Film. New York: Palgrave Macmillan, 2004. Print.

Brunner, Edward. Cold War Poetry. Urbana, IL: University of Illinois Press, 2001. Print.

Chafe, William H. The Unfinished Journey: American Since World War II. 3 rd ed. New York: Oxford University Press, 1995. Print.

Clapson, Mark. Suburban Century: Social Change and Urban Growth in England and the United States. Oxford: Berg, 2003. Print.

Collins, Billy. Aimless Love: New and Selected Poems. New York: Random House, 2013. Print.

--. Sailing Alone around the Room: New and Selected Poems. New York: Random House, 2001. Print.

Deresiewicz, William. "“A Great Symphony of American Junk." New Republic, 9 September 2014. Web. Accessed 10 February 2019. https://newrepublic. com/article/119200/updike-reviewedwilliam-deresiewicz.

Field, Edward (ed). A Geography of Poets. New York: Bantam, 1979. Print.

Gill, Jo. The Poetics of the American Suburbs. New York: Palgrave Macmillan, 2013. Print.

Hayden, Dolores. A Field Guide to Sprawl. New York: Norton, 2004. Print. Hugo, Richard. The Triggering Town: Lectures and Essays on Poetry and Writing. New York: Norton, 1982. Print.

Jackson, Kenneth T. Crabgrass Frontier: The Suburbanization of the United States. New York: Oxford University Press, 1985. Print.

Kunstler, James Howard. The Geography of Nowhere: The Rise and Decline of 
America's Man-Made Landscape. New York: Touchstone, 1993. Print.

Lawrence, D. H. Selected Literary Criticism. Edited by Anthony Beal. New York: Viking, 1966. Print.

Leithauser, Brad. “Updike's Naked Poetry." New Criterion, vol. 34, no. 2. 2015: 10-17. Print.

Levis, Larry. "Eden and My Generation." Conversant Essays: Contemporary Poets on Poetry. Ed. James McCorkle. Detroit: Wayne State University Press, 1990. 466-77. Print.

Lucas, Dave. "Suburban Pastoral." Poetry, vol. 184, no. 4. 2004: 281-2. Print. McGinley, Phyllis. Times Three. New York: Viking, 196o. Print.

McMichael, James. The World At Large: New and Selected Poems, 1971-1996. Chicago: University of Chicago Press, 1996. Print.

McTavish, John. “'Jesus and Elvis' and John Updike's Poetry.” Theology Today, vol. 63, no. 4. 2007: 433-41. Print.

Monacell, Peter. "In the American Grid: Modern Poetry and the Suburbs." Journal of Modern Literature, vol. 35, no. 1. Fall 2011: 122-42. Print.

Perin, Constance. Belonging in America: Reading Between the Lines. Madison, WI: University of Wisconsin Press, 1988. Print.

Psalm 23:6. Bible, New International Version. BibleGateway, 2011. Web. Accessed 30 January 2019. https://www.biblegateway.com/passage/?search$=$ Psalm+23\%3A6\&version=NIV.

Stevens, Wallace. Collected Poetry and Prose. Eds. Frank Kermode and Joan Richardson. New York: Library of America, 1997. Print.

Updike, John. Collected Poems, 1953-1993. New York: Knopf, 1993. Print.

---. Endpoint and Other Poems. New York: Knopf, 20o9. Print.

--.. "In the Cemetery High Above Shillington." Ontario Review, vol. 40. 2014: 25-9. Print.

von Hallberg, Robert. American Poetry and Culture, 1945-1980. Cambridge, MA: Harvard University Press, 1985. Print.

Wallace, David Foster. "John Updike, Champion Literary Phallocrat, Drops One; Is This Finally the End for Magnificent Narcissists?" Observer. 13 October 1997. Web. Accessed 10 February 2019. https://observer. com/1997/10/john-updike-champion-literary-phallocrat-drops-one-is-thisfinally-the-end-for-magnificent-narcissists/

Wallace, Ronald. God Be with the Clown: Humor in American Poetry. Columbia: University of Missouri Press, 1984. Print.

Wilbur, Richard. New and Collected Poems. San Diego: Harcourt, 1988. Print. 


\section{JIŘÍ FLAJŠAR}

JIŘÍ FLAJŠAR is an assistant professor of English at the Faculty of Education, Palacký University, Olomouc, Czech Republic. He is the author of four books on American literature and culture, co-author and editor of seven volumes of criticism, and author of numerous invited lectures and papers at international conferences, several dozen articles in refereed journals, and the recipient of many research grants. He teaches British and American history, culture, and literature. His current research focuses on the ethnic and spatial issues of identity construction in American and British urban culture.

jiri.flajsar@upol.cz 